\title{
Instagram addiction in teenagers: The role of type D personality, self-esteem, and fear of missing out
}

\author{
Wahyu Rahardjo, ${ }^{1 *}$ Indah Mulyani ${ }^{1}$ \\ 1. Faculty of Psychology, Universitas Gunadarma, Depok - Indonesia
}

\begin{abstract}
Instagram addiction is a social phenomenon among teenagers that has been little studied. This study aims to empirically examine the effect of type D personality (social disinhibition and negative affectivity), self-esteem, and fear of missing out (FoMO) on Instagram addiction among adolescents. A total of 259 participants living in Greater Jakarta, Indonesia, with type D personalities with mild to severe addiction were identified through screening results (based on total score). Snowball sampling and regression were used to collect and process the data. The results of the analysis show that together, all the independent variables have an effect of $56.9 \%(\mathrm{p}<.01)$ on Instagram addiction. Partially, only negative affectivity (a type D personality factor) does not affect Instagram addiction $(\beta=0.078, p>.05)$, which means that such addiction is strongly influenced by a combination of external and internal factors. The study illustrates that individuals who have difficulty building social relationships in the real world due to negative self-esteem try to connect with others through social media such as Instagram.
\end{abstract}

Keywords: fear of missing out; Instagram addiction; self-esteem; type D personality

\begin{abstract}
Abstrak: Adiksi Instagram merupakan fenomena sosial di kalangan remaja yang belum terlalu banyak terungkap melalui berbagai hasil penelitian. Penelitian ini bertujuan untuk menguji secara empiris pengaruh kepribadian tipe D (social disinhibition dan negative affectivity), harga diri, dan fear of missing out (FoM0) terhadap adiksi Instagram di kalangan remaja. Sebanyak 259 partisipan yang berdomisili di Jabodetabek dengan kepribadian tipe D yang terlibat dalam adiksi ringan sampai dengan berat diperoleh melalui hasil penyaringan (berdasarkan total skor). Penelitian ini menggunakan snowball sampling dan regresi untuk mengumpulkan dan mengolah data. Hasil analisis menunjukkan bahwa seluruh variabel bebas secara bersama-sama berpengaruh sebesar $56,9 \%(p<0,01)$ terhadap adiksi Instagram. Secara parsial, hanya negative affectivity (salah satu faktor kepribadian tipe D) yang tidak memiliki pengaruh terhadap adiksi Instagram $(\beta=0,078, p>0,05)$, yang artinya adiksi Instagram sangat dipengaruhi oleh kombinasi faktor eksternal sekaligus internal. Penelitian ini memberikan gambaran bahwa individu yang memiliki kesulitan membangun hubungan sosial di dunia nyata karena harga diri negatif mencoba terhubung melalui media sosial seperti Instagram.
\end{abstract}

Kata Kunci: adiksi Instagram; fear of missing out; harga diri; kepribadian tipe D

\footnotetext{
*Corresponding Author: Wahyu Rahardjo (e-mail: wahyu_r@staff.gunadarma.ac.id), Faculty of Psychology, Universitas Gunadarma, Jl. Margonda Raya No 100, Depok 16424-Indonesia.
} 


\section{Introduction}

Generation Z is people who were born in 1993-2005, the majority of which now are currently reaching adolescence. Generation $\mathrm{Z}$ is living in the era of rapidly advancing communication and information technology which enables them to talk to anyone at any time because they are accustomed to interacting and communicating in a constantly connected world through social media (Tulgan, 2013). The current ease of communication is made possible by the presence of smartphones, in addition to computers that connect them to the internet. APJII ${ }^{1}$ (2018) survey results showed that $87.13 \%$ of internet users in Indonesia often use the internet to access social media.

Instagram is the most popular social media platform which is frequently used by teenagers today (Anderson \& Jiang, 2018; Golbeck, 2015; Mulyani, Rahardjo, et al., 2018). Instagram is extensively used by teenagers due to its good interactivity with other applications and its uncanny ability to provide an interesting source of reference for its users (Ibba \& Pani, 2016). Additionally, Instagram is also a social media application equipped with the capability to share high-quality pictures and information about the locations where the snapshots are taken (Manikonda, Hu, \& Kambhampati, 2014). Interesting features of Instagram can entice teenagers to continuously access it and led them to addiction.

The results of previous research showed that 9-10\% of teenage users' Instagram exhibited addictive behaviors (Mulyani, 2019; Mulyani, Mikarsa, et al., 2018). Arguably, 1 in 10 teenagers is show symptoms or manifestations of Instagram

\footnotetext{
${ }^{1}$ Asosiasi Penyelenggara Jasa Internet Indonesia
}

addiction. Although the number of adolescent Instagram addicts is relatively low, studies that can potentially indicate predictors for Instagram addiction are needed to prepare and safeguard Generation $\mathrm{Z}$ and their successors to confront conditions related to technological advances in the future. Results of the previous studies have led the authors to choose the variables of self-esteem, fear of missing out (FoMO), and type D personality as predictors for Instagram addiction behavior among adolescents.

The self-esteem variable was chosen based on previous research which supports that self-esteem influences Instagram addiction (Andreassen et al,, 2017; Balta et al., 2020; Mulyani, Mikarsa, et al,, 2018). Self-esteem is a variable commonly found in adolescent behavior related to social media use because of the frequent social comparison made by the users (Putra, 2018). Self-esteem can be defined as a form of individuals' acceptance, assessment, and respect for themselves. Selfesteem is an evaluation of the difference or gap between self-image (how individuals perceive themselves) and ideal-self (the self they want) to individuals (Ümmet, 2015). Therefore, teenagers with low inequality evaluation capabilities perceive Instagram as one of the social media platforms that enable users to display their desired self-ideal through its features. This in turn will encourage them to spend enormous amount of time accessing the Instagram, and consequently lead the said teenagers into Instagram addiction behavior.

The fear of missing out or FoMO variable was chosen based on previous research results which showed that FoMO is a predictor for Instagram addiction behavior and problematic social media use in general (Blackwell et al., 2017; van Rooij et al., 2018). FoMO is an individual's understanding 
that when they abstain from some activities, other people will get the experience that they should get (Balta et al., 2020). Therefore, teenage users of Instagram with a high level of FoMO 1 wil feel worried about missing the experience they will get when using Instagram. Among the experiences gained by teenagers when using Instagram are information, affection, and interactions with other users that can be obtained through various interesting features of Instagram, such as Instastory. This will then urge to keep their devices close at hand so they fail to control their use of the using social media, and that is one telltale sign of addiction: persistence (Eijnden et al., 2016).

The type D personality variable was chosen based on the results of previous research which showed that individuals with type D personality were positively correlated with Internet addiction in general (Holdoš, 2017). Type D personality is characterized by an individual's susceptibility to stress and illness (Denollet et al., 2010; Williams \& Wingate, 2012) Meanwhile, Internet addiction is divided into five types of behavior, one of which is cyber-relationship addiction, where Instagram addiction enters into cyber-relationship addiction, because the primary purpose and motive for using social media, is to build and maintain relationships, both online and offline (Kuss \& Griffiths, 2011). Individuals with type D tend to have difficulties in controlling affection and suppressing emotional expressions, are uncomfortable, and feel less secure in a crowd so they tend to withdraw from social relations (Denollet, 2000). Therefore, teens with personality type D will opt to spend an excessive amount of time using Instagram to escape social interaction in the real world.
This situation has provided context and sparked the authors' interest in examining the partial or complete influence of type D personality, self-esteem, and fear of missing out on Instagram addiction either partially or completely, and complete to complement previous research.

\section{Method}

Research data were collected using an online questionnaire from Google form that we distributed via WhatsApp. All participants in this study were active Instagram users and had filled out informed consent and research questionnaires anonymously voluntarily. 434 participants (teenagers) were obtained and they were further screened and divided into groups of type D individuals showing low to high Instagram addiction. Subsequent screenings resulted in 259 who had the highest scores.

Instagram addiction in this study was measured using Kircaburun and Griffiths Scales, (2018). This scale has two aspects, namely social effect, and compulsion. A sample item for social effect aspect is " How often do you try to cut down the amount of time you spend on Instagram and fail?" while the sample item for the compulsion aspect is "How often do you find you anticipating when you will go on Instagram again?" This scale has a total of 15 items with 1-6 response categories that range from Never to Always. This scale has a reliability of $\alpha=.910$.

Type D personality in this study was measured using a scale compiled by Denollet $(1998,2005)$. This scale has two aspects: negative affectivity and social inhibition. The sample item for negative affectivity is "I take a gloomy view of things," while sample item for aspects of social inhibition is "I often feel inhibited in social interaction." This scale has a total of 14 items with 
0-4 response categories that range from Very Inadequate to Very Corresponding. The reliability of this scale is $\alpha=.877$.

Self-esteem in this study was measured using a scale compiled by Rosenberg (1965). This unidimensional scale consists of 10 items with response categories ranging from 1 to 5 response categories that range from Very Inadequate to Very Corresponding. A sample item for the selfesteem scale is "I feel I do not have much to be proud of'. The reliability of this scale is $\alpha=.870$.

The fear of missing out (FoMO) in this study was measured using a scale compiled by Przybylski, Murayama, DeHaan, and Gladwell (2013). This scale is unidimensional and consists of 10 items with response categories ranging from 1 to 5 response categories that range from Very Inadequate to Very Corresponding. A sample item for the FoMO scale is " I get anxious when I don't know what my friends are up to". The reliability of this scale is $\alpha=.828$.

For data analysis, this study employed two techniques, correlation and then multiple regression. These techniques were used to find out the effects of each independent variable on dependent variables.

\section{Results}

In this research, the participants were screened twice before we performed data processing. The first screening was done on the Instagram addiction variable. The cutoff point given by Kircaburun and Griffiths (2018) is a score of 38 or an initial score for Instagram addiction at a low level because participants who score 15-37 are classified as not having Instagram addiction. In this phase, of the 434 participants who responded to our online questionnaire, only 285 people showed Instagram addiction.

The second screening was done on type D personality. Cut off point given by Denollet (2005) is a score of $\geq 10$ for each dimension type D personality (negative affectivity and social inhibition) so that individuals with a total score of 0-9 are classified as not having type D personality. In this phase, out of 285 participants involved in addiction, 259 people have a type D personality, which fits the analysis.

Table 1

Participant Demographic Data

\begin{tabular}{llll}
\hline Characteristics & Total & Female & Male \\
\hline City of residence & 55 & 39 & 16 \\
Bekasi & 34 & 23 & 11 \\
Bogor & 44 & 36 & 8 \\
Depok & 100 & 60 & 40 \\
Jakarta & 26 & 19 & 7 \\
Tangerang & & & \\
Education level & 54 & 39 & 15 \\
Senior high school & 205 & 138 & 67 \\
University & 1 & 1 & - \\
Duration using Instagram & 21 & 14 & 7 \\
<1 hour/day & 111 & 38 & 1 \\
1-3 hours/day & 106 & 105 & 1 \\
3-5 hours/day & 20 & 19 & \\
5-8 hours/day & & & \\
$>8$ hours/day & & & \\
\hline
\end{tabular}


The majority of 259 study participants were female $(\mathrm{N}=177 ; 68.3 \%)$ and the rest were male $(\mathrm{N}=82 ; 31.7 \%)$. The mean age of 259 participants as a whole was 18.85 years ( $\mathrm{SD}=1.58)$. Table 1 presents the results of the analysis of the characteristics of the city of origin, level of education, and length of use of Instagram.

Next, we conducted a correlation analysis for each research variable, and the results can be seen in the correlation matrix in Table 2. Based on the results of the correlation analysis it is known that self-esteem ( $r=-.639, \mathrm{p}<.01)$, FoMO $(\mathrm{r}=0.665, \mathrm{p}$ $<.01)$, negative affectivity $(\mathrm{r}=.501, \mathrm{p}<.01)$ and social inhibition $(\mathrm{r}=.488, \mathrm{p}<.01)$ have a very significant correlation with Instagram addiction. The analysis also shows that only self-esteem variables are positively correlated with Instagram addiction and the rest are negatively correlated.
Following the correlation analysis, we conducted a regression analysis to see the magnitude of the effect of each variable and all the variables simultaneously on Instagram addiction. The results of a simple regression analysis showed that only negative affectivity did not influence Instagram addiction. Meanwhile, the biggest influence on Instagram addiction is indicated by FoMO $(\beta=.364, p<.01)$, followed by self-esteem $(\beta=-0.281, p<.01)$, and social inhibition $(\beta=$ $0.221, p<.01)$. Meanwhile, based on the results of multiple regressions, self-esteem variables, FoMO, negative affectivity and social inhibition altogether affected 56.9\% ( $\mathrm{F}=83.765 ; \mathrm{p}<$.01) on Instagram addiction where $43.1 \%$ were influenced by other factors beyond the scope of this study.

The partial or complete results of the regression analysis are presented in Tables 3 and 4 .

Table 2

Correlation Matrix for Each Variable

\begin{tabular}{llllll}
\hline & $\begin{array}{l}\text { Instagram } \\
\text { addiction }\end{array}$ & Self-esteem & FoMO & $\begin{array}{l}\text { Negative } \\
\text { Affectivity }\end{array}$ & $\begin{array}{l}\text { Social } \\
\text { Inhibition }\end{array}$ \\
\hline Instagram addiction & & & & \\
Self-esteem & $-.639^{* *}$ & & & & \\
Fear of missing out & $.65^{* *}$ & $-.630^{* *}$ & & \\
Negative affectivity & $.501^{* *}$ & $-.617^{* *}$ & $.494^{* *}$ & & \\
Social inhibition & $.488^{* *}$ & $-.365^{* *}$ & $.384^{* *}$ & $.316^{* *}$ & \\
Mean & 50.54 & 28.04 & 36.12 & 16.06 & 17.34 \\
SD & 6.34 & 5.13 & 4.38 & 2.53 & 2.40 \\
\hline
\end{tabular}

Note: ${ }^{* *}=\mathrm{p}<.01$

Table 3

Regression Weight of Each Variable on Instagram Addiction

\begin{tabular}{llll}
\hline Aspect & $\beta$ & $\mathrm{t}$ & $\mathrm{sig}$ \\
\hline Self-esteem & -0.281 & -4.694 & $\mathrm{p}<.01$ \\
FoMO & 0.364 & 6.634 & $\mathrm{p}<.01$ \\
Negative affectivity & 0.078 & 1.465 &. $\mathrm{~ns}$ \\
Social inhibition & 0.221 & 4.849 & $\mathrm{p}<.01$ \\
\hline
\end{tabular}


W. Rahardjo, I. Mulyani

Table 4

Regression Weight for Overall Variables for Instagram Addiction

\begin{tabular}{lllll}
\hline Variables & $\mathrm{R}^{2}$ & Adjusted $\mathrm{R}^{2}$ & $\mathrm{~F}$ & sig \\
\hline $\begin{array}{l}\text { Self-esteem, FoM0, negative } \\
\text { affectivity, social inhibition }\end{array}$ & .569 & .562 & 83.765 & $\mathrm{p}<.01$ \\
\hline
\end{tabular}

\section{Discussion}

The negative affectivity aspect does not significantly affect Instagram addiction. This finding is quite interesting to discuss. In some previous studies, negative affectivity is related to any addiction suffered by individuals, especially individuals who have health problems (Denollet, 1991, 2000; Van der Zee et al., 1998). These health problems become a source of stress and cause individuals to lose their positive perception about themselves, negative effects appear (Allen et al., 2019; Williams \& Wingate, 2012).

On the other hand, this negative affectivity does not significantly affect the psychological condition of healthy individuals or those having health issues (Stevenson \& Williams, 2014). At this point, it seems that the participants of this research could be physically healthy individuals so that health problems do not bring about negative effects. Healthier individuals will be free from negative emotions, and vice versa (Finch et al., 2012; Lopez \& Denny, 2019; Nejad et al., 2011).

Interestingly, the actual problems arise from the context of social relations. The oriental culture which upholds togetherness is closely related to social relations (Realo et al., 2004; Vodosek, 2009; Wang \& Liu, 2010). Consequently, when disturbances occur in social relations, the affected persons will get depressed and can experience negative emotions such as depression (Knyazev et al., 2017; Umberson \& Karas Montez, 2010). Indirectly, the finding that negative affectivity does not have a significant effect on Instagram addiction highlights the role of another type D personality aspect, namely social inhibition.

The findings of this research show that social inhibition as an aspect of type $\mathrm{D}$ personality has a strong influence on Instagram addiction. Individuals with high social inhibition tend to have difficulty in expressing emotions and warmth in social relations, so they appear shy, tend to be quiet and introverted, do not trust others too much, and avoid social contact (de Moor et al., 2018; Denollet, 2000, 2013). This deficiency causes individuals to easily feel social anxiety (Kaplan et al., 2015; Newby et al., 2017). This happens because individuals are less able to assess social situations with clarity, especially those that make them feel stressed, and then find negative justifications for what happens into their social existence (Grynberg et al., 2012; O'Riordan et al., 2020). This social anxiety can then be reduced when individuals only need to communicate with others virtually, without the need to have face to face communication (Yen et al., 2012). This is supported by several previous studies who mention that the greater the social anxiety is felt by an individual, the greater is the tendency for him to show social media addictions such as Instagram, Facebook, and even Youtube (de Bérail et al., 2019; Foroughi et al., 2019; Yurdagül et al., 2019).

Individuals who enjoy good social relations with parents and peers in the real world are more resistant to mobile phones, internet, and social 
media addictions (Ihm, 2018; Jia \& Jia, 2016). Conversely, individuals who find it difficult to develop warm social relations in the real world will try their best to do it in cyberspace (PrizantPassal et al., 2016). Relationships in cyberspace provide a different kind of comfort that they do not get when they directly socialize with people. As a result, the intensity of face-to-face interactions is reduced and individuals feel more comfortable in communicating and developing social relations in cyberspace (Kircaburun et al., 2018).

Interaction in cyberspace through social media takes place to compensate for the loss of affection that is normally gained in social relations in the real world (D'Arienzo et al., 2019). The harder it is for an individual to build warm social relations in the real world, the more likely he is to develop social media addiction (Holdoš, 2017; Jia \& Jia, 2016).

The findings in this research are also in line with some previous research which states that self-esteem influences social media addiction (Andreassen et al., 2017; Busalim, Masrom, \& Binti Wan Zakaria, 2019; Kircaburun, 2016). Individuals with negative self-esteem become more sensitive to criticism and feedback that makes them feel uncomfortable (Apaolaza et al, 2019). Conversely, individuals with positive selfesteem can welcome criticism because it does not focus on their shortcomings. Consequently, those individuals become more cautious and wary of social relations and tend to be self-protective in social relations (Sowislo \& Orth, 2013).

Andreassen (2015) states that self-evaluation like the perception of oneself as a valuable person or otherwise would trigger the activation of certain behaviors such as the use of social media. This can happen because it helps individuals to continue building social relations with minimal negative evaluation. After all, there is no need for face-to-face interactions. This feeling of worthlessness is anticipated by active participation in social media by strengthening social networks, including the belief that having a lot of friends or followers will create a great and valuable feeling (Andreassen et al., 2017; Gallagher, 2017; Wilcox \& Stephen, 2013).

At this point, the individual's self-esteem does seem to depend on the existence of peers or followers on his social media. This form of selfesteem focuses the individual on the fact that for himself, friends are the greatest source of appreciation. This self-esteem is unstable because it is very dependent and focuses on peer evaluation (Gorrese \& Ruggieri, 2013; Kang, 2019). This form of self-esteem encourages individuals to use social media more intensely (Pettijohn II et al., 2012; Salim et al., 2017), because they need many positive responses from their friends on social media to keep feeling valuable (Valkenburg \& Peter, 2011). Several previous studies confirmed the effect of self-esteem originating from these peers on social media addiction (Kanat-Maymon et al., 2018; Saiphoo et al., 2020).

On the other hand, fear of missing out or FoMO also influences social media addictions like Instagram. This finding is following previous studies by Balta et al. (2020). This can happen because teenagers who tend to be afraid of losing the latest information about their friends and the fear of being left behind by friends seek to satisfy those needs on Instagram. Individuals with great fear of missing out tend to have a greater number of friends with more complex networks on social media (Oberst et al., 2017). 
Instagram itself is a social media platform that highly acclimates openness and self-expression in social relations or friendship (Salim et al., 2017; Shane-Simpson et al., 2018), even for establishing communication with strangers for social adjustments (Yang \& Lee, 2020). This is a form of media richness or the condition of communication media that provides a wide variety of communication features, especially for virtual communication (Shang et al., 2017; Xu \& Tan, 2012). The Lee and Borah study (2020) emphasized the importance of the issue of media richness on Instagram as the basis for the formation of social relations and friendship in cyberspace. As a result, this attempt to maintain cyberspace social relations to meet the needs of individual affiliations with a high fear of missing out causes him to develop social media addiction (Elhai et al., 2016; Kircaburun et al., 2018; Oberst et al., 2017).

Individuals will show some biases when shifting the fulfillment of perceived needs in the use of social media with the fact that they have developed addictive behaviors. To put it another way, individuals become unaware that their behavior in making friends in cyberspace has led them into social media addiction because of fear of losing information and closeness with friends (Wegmann etal., 2017).

The findings in this research can be further interpreted using the social skills deficit theory. This theory seeks to explain that many psychosocial problems can occur in individuals, especially children and adolescents, due to their poor social skills (Caplan, 2003; Levitan \& Nardi, 2009; Segrin, 1996, 2001). Individual social skills should be seen from the way they communicate, and make social adjustments to build warm social relations and ease their loneliness (Chou et al.,
2017; Zhang et al., 2014). Poor social skills can occur due to several things, for example, special internal characteristics such as loneliness, depression, negative self-esteem (Caplan, 2003; Segrin, 1990, 1996, 2001). Participants in this study show the tendency of type D personality, especially in the aspect of social inhibition, negative self-esteem, and fear of missing out or FoMO which has proved to affect Instagram addiction.

Caplan (2003) then goes on to emphasize that computer-based communication provides many interesting features for individuals, especially those characterized by poor social competence, to help them maintain warm social relations. Even for individuals with poor social competence, communication in cyberspace is often used as an exercise to improve face-to-face communication skills (Campbell et al., 2006). Conversely, individuals with good social competence tend to display good online communication (Reich, 2017; Valkenburg \& Peter, 2008).

Instagram then fulfills this need through a complex set of features, and some of them can encourage individuals to use it excessively (Balakrishnan \& Griffiths, 2018). Individuals with poor social competence could establish social relationships online (Shaw \& Black, 2008). Good responses from Instagram followers can then provide them with positive and valuable feelings (Kircaburun \& Griffiths, 2018). When they feel that Instagram creates a good effect and potentially fills their needs, then they will be compelled to repeat their behavioral pattern so that it becomes an addiction.

\section{Conclusion}


Several conclusions can be drawn from this study. Firstly, type D personality, especially aspects of social inhibition, self-esteem, and fear of missing out have a significant effect on an individual's Instagram addiction. It means that external factors like fear of missing out and selfesteem (a combination of external and internal factors) affecting the Internet addiction are stronger than internal factor such as type D personality. Secondly, the findings of this research can try to provide an illustration that among individuals who are less able to build warm realworld social relations because they have negative self-esteem and are less comfortable in the social environment, the need to establish communication and remain socially related remains large so that they will try to stay connected with people through the social media.

Suggestions for future research. Firstly, there are no external variables involved as predictors in this research related to Instagram addiction. Secondly, if personality is considered to be one of the important factors that influence social media addiction such as Instagram, then the Big Five can be taken into consideration as the other predictor variable.]

\section{References}

Allen, S. F., Wetherell, M. A., \& Smith, M. A. (2019). A one-year prospective investigation of Type D personality and self-reported physical health. Psychology \& Health, 34(7), 773-795. https://doi.org/10.1080/08870446.2019.1568431

Anderson, M., \& Jiang, J. (2018). This is how the relationship between teenagers and social media is changing.https://www.weforum.org/agenda/2018/06/teens-social-media-technology-2018

Andreassen, C. S. (2015). Online social network site addiction: A comprehensive review. Current Addiction Reports, 2(2), 175-184. https://doi.org/10.1007/s40429-015-0056-9

Andreassen, C. S., Pallesen, S., \& Griffiths, M. D. (2017). The relationship between addictive use of social media, narcissism, and self-esteem: Findings from a large national survey. Addictive Behaviors, 64, 287-293. https://doi.org/10.1016/j.addbeh.2016.03.006

Apaolaza, V., Hartmann, P., D'Souza, C., \& Gilsanz, A. (2019). Mindfulness, compulsive nobile social media use, and derived stress: The mediating roles of self-esteem and social anxiety. Cyberpsychology, Behavior, and Social Networking, 22(6), 388-396. https://doi.org/10.1089/cyber.2018.0681

Asosiasi Penyelenggara Jasa Internet Indonesia. (2018). Infografis: Penetrasi dan perilaku pengguna internet Indonesia. Survey $2017 . \quad$ web.kominfo.go.id. https://web.kominfo.go.id/sites/default/files/Laporan Survei APJII_2017_v1.3.pdf

Balakrishnan, J., \& Griffiths, M. D. (2018). An exploratory study of "selfitis" and the development of the Selfitis Behavior Scale. International Journal of Mental Health and Addiction, 16(3), 722-736. https://doi.org/10.1007/s11469-017-9844-x

Balta, S., Emirtekin, E., Kircaburun, K., \& Griffiths, M. D. (2020). Neuroticism, trait fear of missing out, and phubbing: The mediating role of state fear of missing out and problematic Instagram use. International Journal of Mental Health and Addiction, 18(3), 628-639. https://doi.org/10.1007/s11469-018-9959-8 
Blackwell, D., Leaman, C., Tramposch, R., Osborne, C., \& Liss, M. (2017). Extraversion, neuroticism, attachment style and fear of missing out as predictors of social media use and addiction. Personality and Individual Differences, 116,69-72. https://doi.org/10.1016/j.paid.2017.04.039

Busalim, A. H., Masrom, M., \& Binti Wan Zakaria, W. N. (2019). The impact of Facebook addiction and self-esteem on students' academic performance: A multi-group analysis. Computers \& Education, 142, 103651. https://doi.org/10.1016/j.compedu.2019.103651

Campbell, A. J., Cumming, S. R, \& Hughes, I. (2006). Internet use by the socially fearful: Addiction or therapy? CyberPsychology \& Behavior, 9(1), 69-81. https://doi.org/10.1089/cpb.2006.9.69

Caplan, S. E. (2003). Preference for online social interaction. Communication Research, 30(6), 625-648. https://doi.org/10.1177/0093650203257842

Chou, W.-J., Huang, M.-F., Chang, Y.-P., Chen, Y.-M., Hu, H.-F., \& Yen, C.-F. (2017). Social skills deficits and their association with Internet addiction and activities in adolescents with attentiondeficit/hyperactivity disorder. Journal of Behavioral Addictions, 6(1), 42-50. https://doi.org/10.1556/2006.6.2017.005

D’Arienzo, M. C., Boursier, V., \& Griffiths, M. D. (2019). Addiction to social media and attachment styles: A systematic literature review. International Journal of Mental Health and Addiction, 17(4), 10941118. https://doi.org/10.1007/s11469-019-00082-5

de Bérail, P., Guillon, M., \& Bungener, C. (2019). The relations between YouTube addiction, social anxiety and parasocial relationships with YouTubers: A moderated-mediation model based on a cognitive-behavioral framework. Computers in Human Behavior, 99, 190-204. https://doi.org/10.1016/j.chb.2019.05.007

de Moor, E. L., Denollet, J., \& Laceulle, O. M. (2018). Social inhibition, sense of belonging and vulnerability to internalizing problems. Journal of Affective Disorders, 225, 207-213. https://doi.org/10.1016/j.jad.2017.08.034

Denollet, J. (1991). Negative affectivity and repressive coping: pervasive influence on self-reported mood, health, and coronary-prone behavior. Psychosomatic Medicine, 53(5), 538-556. https://doi.org/10.1097/00006842-199109000-00005

Denollet, J. (1998). Personality and coronary heart disease: The type-D scale-16 (DS16). Annals of Behavioral Medicine, 20(3), 209-215. https://doi.org/10.1007/BF02884962

Denollet, J. (2000). Type D personality: A potential risk factor refined. Journal of Psychosomatic Research, 49(4), 255-266. https://doi.org/10.1016/S0022-3999(00)00177-X

Denollet, J. (2005). DS14: Standard assessment of negative affectivity, social inhibition, and Type D $\begin{array}{llll}\text { personality. } & \text { Psychosomatic } & \text { Medicine, } & \text { 87(1), }\end{array}$ https://doi.org/10.1097/01.psy.0000149256.81953.49

Denollet, J. (2013). Type-D personality. In M. D. Gellman \& J. R. Turner (Eds.), Encyclopedia of behavior medicine (pp. 2014-2018). Springer.

Denollet, J., Schiffer, A. A., \& Spek, V. (2010). A general propensity to psychological distress affects cardiovascular outcomes. Circulation: Cardiovascular Quality and Outcomes, 3(5), 546-557. https://doi.org/10.1161/CIRCOUTCOMES.109.934406

Eijnden, R. J. J. M. van den, Lemmens, J. S., \& Valkenburg, P. M. (2016). The social media disorder scale. Computers in Human Behavior, 61, 478-487. https://doi.org/10.1016/j.chb.2016.03.038 
Elhai, J. D., Levine, J. C., Dvorak, R. D., \& Hall, B. J. (2016). Fear of missing out, need for touch, anxiety and depression are related to problematic smartphone use. Computers in Human Behavior, 63, 509516. https://doi.org/10.1016/j.chb.2016.05.079

Finch, J. F., Baranik, L. E., Liu, Y., \& West, S. G. (2012). Physical health, positive and negative affect, and personality: A longitudinal analysis. Journal of Research in Personality, 46(5), 537-545. https://doi.org/10.1016/j.jrp.2012.05.013

Foroughi, B., Iranmanesh, M., Nikbin, D., \& Hyun, S. S. (2019). Are depression and social anxiety the missing link between Facebook addiction and life satisfaction? The interactive effect of needs and self-regulation. Telematics and Informatics, 43, 101247. https://doi.org/10.1016/j.tele.2019.101247

Gallagher, S. M. (2017). The influence on social media on teens' self-esteem. Rowan University.

Golbeck, J. (2015). Introduction to social media investigation: A hands-on approach. Elsevier.

Gorrese, A., \& Ruggieri, R. (2013). Peer attachment and self-esteem: A meta-analytic review. Personality and Individual Differences, 55(5), 559-568. https://doi.org/10.1016/j.paid.2013.04.025

Grynberg, D., Gidron, Y., Denollet, J., \& Luminet, O. (2012). Evidence for a cognitive bias of interpretation toward threat in individuals with a Type D personality. Journal of Behavioral Medicine, 35(1), 95-102. https://doi.org/10.1007/s10865-011-9351-7

Holdoš, J. (2017). Type D personality in the prediction of internet addiction in the young adult population of Slovak internet users. Current Psychology, 36(4), 861-868. https://doi.org/10.1007/s12144-016-9475-6

Ibba, S., \& Pani, F. (2016). Digital libraries: The challenge of integrating instagram with a taxonomy for content nanagement. Future Internet, 8(4), 16. https://doi.org/10.3390/fi8020016

Ihm, J. (2018). Social implications of children's smartphone addiction: The role of support networks and social engagement. Journal of Behavioral Addictions, 7(2), 473-481. https://doi.org/10.1556/2006.7.2018.48

Jia, R., \& Jia, H. H. (2016). Maybe you should blame your parents: Parental attachment, gender, and problematic Internet use. Journal of Behavioral Addictions, 5(3), 524-528. https://doi.org/10.1556/2006.5.2016.059

Kanat-Maymon, Y., Almog, L., Cohen, R., \& Amichai-Hamburger, Y. (2018). Contingent self-worth and Facebook addiction. Computers in Human Behavior, 88, 227-235. https://doi.org/10.1016/j.chb.2018.07.011

Kang, Y. (2019). The relationship between contingent self-esteem and trait self-esteem. Social Behavior and Personality: An International Journal, 47(2), 1-19. https://doi.org/10.2224/sbp.7575

Kaplan, S. C., Levinson, C. A., Rodebaugh, T. L., Menatti, A., \& Weeks, J. W. (2015). Social anxiety and the big five personality traits: The interactive relationship of trust and openness. Cognitive Behaviour Therapy, 44(3), 212-222. https://doi.org/10.1080/16506073.2015.1008032

Kircaburun, K. (2016). Self-esteem, daily internet use and social media addiction as predictors of depression among Turkish adolescents. Journal of Education and Practice, 7(24), 64-72.

Kircaburun, K., Alhabash, S., Tosuntaș, Ș. B., \& Griffiths, M. D. (2018). Uses and gratifications of problematic social media use among university students: A simultaneous examination of the Big Five of Personality Traits, Social Media Platforms, and Social Media Use Motives. International Journal of Mental Health and Addiction, 18(3), 525-547. https://doi.org/10.1007/s11469-018-9940-6 
Kircaburun, K., \& Griffiths, M. D. (2018). Instagram addiction and the Big Five of personality: The mediating role of self-liking. Journal of Behavioral Addictions, 7(1), 158-170. https://doi.org/10.1556/2006.7.2018.15

Knyazev, G. G., Kuznetsova, V. B., Savostyanov, A. N., \& Dorosheva, E. A. (2017). Does collectivism act as a protective factor for depression in Russia? Personality and Individual Differences, 108, 26-31. https://doi.org/10.1016/j.paid.2016.11.066

Kuss, D. J., \& Griffiths, M. D. (2011). Online social networking and addiction--A review of the psychological literature. International Journal of Environmental Research and Public Health, 8(9), 3528-3552. https://doi.org/10.3390/ijerph8093528

Lee, D. K. L., \& Borah, P. (2020). Self-presentation on Instagram and friendship development among young adults: A moderated mediation model of media richness, perceived functionality, and openness. Computers in Human Behavior, 103, 57-66. https://doi.org/10.1016/j.chb.2019.09.017

Levitan, M. N., \& Nardi, A. E. (2009). Social skill deficits in socially anxious subjects. The World Journal of Biological Psychiatry, 10(4-3), 702-709. https://doi.org/10.1080/15622970802255919

Lopez, R. B., \& Denny, B. T. (2019). Negative affect mediates the relationship between use of emotion regulation strategies and general health in college-aged students. Personality and Individual Differences, 151, 109529. https://doi.org/10.1016/j.paid.2019.109529

Manikonda, L., Hu, Y., \& Kambhampati, S. (2014). Analyzing user activities, demographics, social network structure and user-generated content on Instagram.

Mulyani, I. (2019). Model teoritis kecenderungan adiksi Instagram pada remaja ditinjau dari konsep diri, kepribadian narsisistik, dan kompetensi sosial. Universitas Gunadarma.

Mulyani, I., Mikarsa, H. L., \& Puspitawati, I. (2018). Perilaku adiksi pada Instagram di kalangan remaja. Seminar Nasional PascaSarjana Universitas Gadjah Mada.

Mulyani, I., Rahardjo, W., Citra, A. F., Damariyanti, M., Saputra, M., Ayuningsih, A. M., \& Siahay, M. M. (2018). The effect of neuroticism and loneliness to SNS addiction on social media users. The 6th ARUPS Congress: Driving Mental Revolution in the Psychological Century: Enhancing Psychological Services for a Better Future.

Nejad, E. mohammadi H., Besharat, M. A., Haddadi, P., \& Abdolmanafi, A. (2011). Mediation effects of positive and negative affects on the relationship between perfectionism and physical health. Procedia - Social and Behavioral Sciences, 30, 176-181. https://doi.org/10.1016/j.sbspro.2011.10.035

Newby, J., Pitura, V. A., Penney, A. M., Klein, R. G., Flett, G. L., \& Hewitt, P. L. (2017). Neuroticism and perfectionism as predictors of social anxiety. Personality and Individual Differences, 106, 263267. https://doi.org/10.1016/j.paid.2016.10.057

O’Riordan, A., Howard, S., \& Gallagher, S. (2020). Type D personality and life event stress: The mediating effects of social support and negative social relationships. Anxiety, Stress, \& Coping, 33(4), 452465. https://doi.org/10.1080/10615806.2020.1746284

Oberst, U., Wegmann, E., Stodt, B., Brand, M., \& Chamarro, A. (2017). Negative consequences from heavy social networking in adolescents: The mediating role of fear of missing out. Journal of Adolescence, 55, 51-60. https://doi.org/10.1016/j.adolescence.2016.12.008

Pettijohn II, T. F., LaPiene, K. E., Pettijohn, T. F., \& Horting, A. L. (2012). Relationships between Facebook Intensity, Friendship Contingent Self-Esteem, and Personality in U.S. College Students. 
Cyberpsychology: Journal of Psychosocial Research on Cyberspace, 6(1), 1-8. https://doi.org/10.5817/CP2012-1-2

Prizant-Passal, S., Shechner, T., \& Aderka, I. M. (2016). Social anxiety and internet use - A meta-analysis: What do we know? What are we missing? Computers in Human Behavior, 62, 221-229. https://doi.org/10.1016/j.chb.2016.04.003

Putra, J. S. (2018). Peran Syukur sebagai Moderator Pengaruh Perbandingan Sosial terhadap Selfesteem pada Remaja Pengguna Media Sosial. Psikohumaniora: Jurnal Penelitian Psikologi, 3(2), 197-210. https://doi.org/10.21580/pjpp.v3i2.2650

Realo, A., Kästik, L., \& Allik, J. (2004). The relationships between collectivist attitudes and elementary forms of human relations: Evidence from Estonia. Journal of Social and Personal Relationships, 21(6), 779-794. https://doi.org/10.1177/0265407504047837

Reich, S. M. (2017). Connecting offline social competence to online peer interactions. Psychology of Popular Media Culture, 6(4), 291-310. https://doi.org/10.1037/ppm0000111

Rosenberg, M. (1965). Society and the adolescent self-image. Princeton University Press.

Saiphoo, A. N., Dahoah Halevi, L., \& Vahedi, Z. (2020). Social networking site use and self-esteem: A metaanalytic review. Personality and Individual Differences, 153, 109639. https://doi.org/10.1016/j.paid.2019.109639

Salim, F., Rahardjo, W., Tanaya, T., \& Qurani, R. (2017). Are self-presentation influenced by friendshipcontingent self-esteem and fear of missing out? Makara Human Behavior Studies in Asia, 21(2), 70-82. https://doi.org/10.7454/mssh.v21i2.3502

Segrin, C. (1990). A meta-analytic review of social skill deficits in depression. Communication Monographs, 57(4), 292-308. https://doi.org/10.1080/03637759009376204

Segrin, C. (1996). The relationship between social skills deficits and psychosocial problems. Communication Research, 23(4), 425-450. https://doi.org/10.1177/009365096023004005

Segrin, C. (2001). Social skills and negative life events: Testing the deficit stress generation hypothesis. Current Psychology, 20(1), 19-35. https://doi.org/10.1007/s12144-001-1001-8

Shane-Simpson, C., Manago, A., Gaggi, N., \& Gillespie-Lynch, K. (2018). Why do college students prefer Facebook, Twitter, or Instagram? Site affordances, tensions between privacy and selfexpression, and implications for social capital. Computers in Human Behavior, 86, 276-288. https://doi.org/10.1016/j.chb.2018.04.041

Shang, S. S. C., Wu, Y.-L., \& Li, E. Y. (2017). Field effects of social media platforms on information-sharing continuance: Do reach and richness matter? Information \& Management, 54(2), 241-255. https://doi.org/10.1016/j.im.2016.06.008

Shaw, M., \& Black, D. W. (2008). Internet addiction: Definition, assessment, epidemiology and clinical management. CNS Drugs, 22(5), 353-365. https://doi.org/10.2165/00023210-20082205000001

Sowislo, J. F., \& Orth, U. (2013). Does low self-esteem predict depression and anxiety? A meta-analysis of longitudinal studies. Psychological Bulletin, 139(1), 213-240. https://doi.org/10.1037/a0028931

Stevenson, C., \& Williams, L. (2014). Type D personality, quality of life and physical symptoms in the general population: A dimensional analysis. Psychology \& Health, 29(3), 365-373. https://doi.org/10.1080/08870446.2013.856433 
Tulgan, B. (2013). Meet Generation Z: The second generation within the giant "millennial" cohort. RainmakerThinking.Inc.

Umberson, D., \& Karas Montez, J. (2010). Social relationships and health: A flashpoint for health policy. Journal of Health and Social Behavior, 51(1_suppl), S54-S66. https://doi.org/10.1177/0022146510383501

Ümmet, D. (2015). Self esteem among college students: A study of satisfaction of basic psychological needs and some variables. Procedia - Social and Behavioral Sciences, 174, 1623-1629. https://doi.org/10.1016/j.sbspro.2015.01.813

Valkenburg, P. M., \& Peter, J. (2008). Adolescents' identity experiments on the internet. Communication Research, 35(2), 208-231. https://doi.org/10.1177/0093650207313164

Valkenburg, P. M., \& Peter, J. (2011). Online communication among adolescents: An integrated model of its attraction, opportunities, and risks. Journal of Adolescent Health, 48(2), 121-127. https://doi.org/10.1016/j.jadohealth.2010.08.020

Van der Zee, K., Oldersma, F., Buunk, B. P., \& Bos, D. (1998). Social comparison preferences among cancer patients as related to neuroticism and social comparison orientation. Journal of Personality and Social Psychology, 75(3), 801-810. https://doi.org/10.1037/00223514.75.3.801

van Rooij, A. J., Lo Coco, G., De Marez, L., Franchina, V., \& Abeele, M. Vanden. (2018). Fear of missing out as a predictor of problematic social media use and phubbing behavior among flemish adolescents. International Journal of Environmental Research and Public Health, 15(10). https://doi.org/10.3390/ijerph15102319

Vodosek, M. (2009). The relationship between relational models and individualism and collectivism: Evidence from culturally diverse work groups. International Journal of Psychology, 44(2), 120128. https://doi.org/10.1080/00207590701545684

Wang, G., \& Liu, Z.-B. (2010). What collective? Collectivism and relationalism from a Chinese perspective. Chinese Journal of Communication, 3(1), 42-63. https://doi.org/10.1080/17544750903528799

Wegmann, E., Oberst, U., Stodt, B., \& Brand, M. (2017). Online-specific fear of missing out and Internetuse expectancies contribute to symptoms of Internet-communication disorder. Addictive Behaviors Reports, 5, 33-42. https://doi.org/10.1016/j.abrep.2017.04.001

Wilcox, K., \& Stephen, A. T. (2013). Are close friends the enemy? Online social networks, self-esteem, and self-control. Journal of Consumer Research, 40(1), 90-103. https://doi.org/10.1086/668794

Williams, L., \& Wingate, A. (2012). Type D personality, physical symptoms and subjective stress: The mediating effects of coping and social support. Psychology \& Health, 27(9), 1075-1085. https://doi.org/10.1080/08870446.2012.667098

Xu, H., \& Tan, B. C. Y. (2012). Why do I keep checking Facebook: Effects of message characteristics on the formation of social network services addiction. ICIS.

Yang, C., \& Lee, Y. (2020). Interactants and activities on Facebook, Instagram, and Twitter: Associations between social media use and social adjustment to college. Applied Developmental Science, 24(1), 62-78. https://doi.org/10.1080/10888691.2018.1440233

Yen, J.-Y., Yen, C.-F., Chen, C.-S., Wang, P.-W., Chang, Y.-H., \& Ko, C.-H. (2012). Social anxiety in online and real-life interaction and their associated factors. Cyberpsychology, Behavior, and Social Networking, 15(1), 7-12. https://doi.org/10.1089/cyber.2011.0015 
Yurdagül, C., Kircaburun, K., Emirtekin, E., Wang, P., \& Griffiths, M. D. (2019). Psychopathological consequences related to problematic Instagram use among adolescents: The mediating role of body image dissatisfaction and moderating role of gender. International Journal of Mental Health and Addiction, 1-13. https://doi.org/10.1007/s11469-019-00071-8

Zhang, F., You, Z., Fan, C., Gao, C., Cohen, R., Hsueh, Y., \& Zhou, Z. (2014). Friendship quality, social preference, proximity prestige, and self-perceived social competence: Interactive influences on children's loneliness. Journal of School Psychology, 52(5), 511-526. https://doi.org/10.1016/j.jsp.2014.06.001 
This page has been intentionally left blank. 